\title{
Drone-dronningen: Voyeurisme, intimitet og paranoia i tv-serien Homeland
}

Andreas Immanuel Graae, Ph.d.-stipendiat, Litteraturvidenskab, Syddansk Universitet

Kamikazepiloten: Min krop er et våben. Dronen: Mit våben har ingen krop."

- Chamayou 2015, 84

I hovedværket A Theory of the Drone (2015) trækker den franske filosof Grégoire Chamayou linjerne hårdt op mellem to typer krigere: Selvmordsbomberen og dronepiloten. Hvor selvmordsbomberen, herunder kamikazepiloten, med sin handling foretager den ultimative ofring af egen krop, markerer dronepiloten omvendt et totalt fravær af krop i kampzonen; de repræsenterer to politiske og affektive logikker, der ofte modstilles i den akademiske dronedebat såvel som i populærkulturelle repræsentationer af dronekrig. ${ }^{1}$

Opfattelsen af dronekrig som en grundlæggende kropsløs og virtuel affære underst $\varnothing$ ttes af udbredte forestillinger og fordomme om droneoperationer som ren simulation eller ligefrem et computerspil, der producerer en 'PlayStation-mentalitet' blandt piloterne (Chamayou 2015, 107; Gregory 2014, 9). Der skal ikke herske tvivl om, at de senere årtiers teknologiske fremskridt har øget militærindustriens interesse for simulationer, computergenerede modeller, netværk og algoritmer (Derian 2009). Men selvom skærmkrigerens manglende kropslige involvering i begivenhederne på slagmarken kan stilles op over for selvmordsbomberens ultimative kropslige offer, betyder det ikke nødvendigvis, at følelsesmæssig indlevelse og erfaring er totalt fraværende i dronekrig. Tværtimod tyder talrige rapporter om psykiske nedbrud og PTSD-diagnoser blandt dronepiloterne på væsentlig mental fordybelse og emotionel indlevelsesevne (Chamayou 2015, 106).

\footnotetext{
${ }^{1}$ For eksempel tegner poprock-gruppen Muse i albummet Drones (2015) et dehumaniseret billede af dronekrig, hvor der er "no recourse, and there is no one behind the wheel," som det hedder på tracket 'Reapers.'
} 
Adskillige nyere film og tv-serier adresserer denne problematik i deres repræsentationer af dronekrig. Eksempelvis dyrker film som Drones (2013), Goodkill (2014), Full Contact (2015) og National Bird (2016) den martrede dronepilot som en antihelt, traumatiseret af rutinedrab på civile fra flere tusind kiloters sikker afstand. Som vinduer til specifikke erfaringsmodi har sådanne populærkulturelle repræsentationer en væsentlig indflydelse på, hvad man kunne kalde 'dronens imaginære'; det vil sige de billeder, forestillinger og følelser, der knytter sig til dronekrig i den brede offentlighed. Der er imidlertid dvælet overraskende lidt ved karakteren af de følelser, som disse imaginationer tegner af det nye, ambivalente nærvær, herunder hvilke kropslige erfaringer og følelser, der knytter sig til dronens kobling af det på én gang distancerede og nærværende blik på slagmarken. Disse sammensatte følelser og erfaringer kan et kulturanalytisk blik på populærkulturens bidrage til at kortlægge og diagnosticere.

Med geografen og droneteoretikeren Derek Gregorys ord kan denne nye kobling af nærvær og distance i erfaringen af dronekrig beskrives som en art 'voyeuristisk intimitet' (Gregory 2014, 8), der invaderer og infiltrerer de ellers så 'usårlige' ${ }^{2}$ dronepiloters kroppe. For mig at se er idéen om voyeuristisk intimitet uden tvivl rammende til at beskrive dronepiloternes ambivalente visuelle erfaring - en erfaring, Gregory også har beskrevet som "remote split operations" (Gregory 2014, 8), det vil sige en slags 'spaltet' oplevelse af at være både her og der, på samme tid fjern og nær. Ifølge Gregory tager det typisk piloterne 6-12 måneder at tilpasse sig denne spaltede erfaring, som starter med en følelse af 'spøgelsesagtig' uvirkelighed (Gregory 2014, 10). En beskrivelse, der stemmer godt overens med forestillingen om følelsesmæssigt afkoblede PlayStation-krigere. Efter absorptionsperioden udvikler oplevelsen sig dog tilsyneladende $\mathrm{i}$ en alvorligere retning og bliver mere personlig og nærværende, men ikke desto mindre også mere rutinepræget: "You become emotionally distant," som en dronepilot fortæller Omer Fast i filmen 5.000 Feet is the Best (2013) og bekræfter dermed det komplicerede forhold mellem følelsesmæssig nærhed og distance i nutidens dronekrige.

Gregory henter sit begreb om 'voyeuristisk intimitet' fra journalisten Matthew Power. I et interview med den (formentlig mest citerede) traumatiserede dronepilot, Brandon Bryant, ${ }^{3}$ parafraserer han Bryants voyeuristiske oplevelse af at observere sine mål "[...] drikke te med venner, lege med deres børn, have sex med deres koner på hustage, krympe sig under tæpper, [...] og [gå til] fodboldkampe og bryllupper" (Power 2013). Med andre ord en praksis, hvor selv den mest intime detalje i fjendens privatsfære overvåges af dronevoyeuren. Det intensive fokus på intim luftovervågning har Gregory også introduceret andetsteds som en 'kulturel vending' i senmoderne krig; en vending hvor et "rush to the intimate" i tiltagende grad er blevet centralt i militære

\footnotetext{
${ }^{2}$ Forestillingen om den usårlige dronekriger kommer for eksempel til udtryk i et citat fra en Air Force officer, David Deptula, der beskriver, hvordan dronekrig "[...] allow you to project power without projecting vulnerabilities." (Chamayou 2009, 12).

${ }^{3}$ Bryants vidnesbyrd om en dronepilots psykologiske erfaring hører til sjældenhederne, hvilket formentlig også er derfor han som kilde er uhyre citeret $\mathrm{i}$ såvel droneforskningen som populærkulturen, eftersom flere film om dronekrig bygger på hans forklaringer (Chamayou 2015, 121ff).
} 
operationer (Gregory 2008; 2014, 9). Den kulturelle vending handler kort sagt om at 'kende sin fjende', som Sun Tzu oprindeligt advokerede for, ${ }^{4}$ men det er et intimt bekendtskab bogstavelig talt taget til helt nye højder.

I det følgende vil jeg dykke dybere ned i denne voyeuristiske intimitet og - fra et kulturanalytisk perspektiv - udforske, hvordan den som affekt spiller sammen med andre følelser og erfaringer af at føre krig fra skærmen fjernt fra slagmarken. Den grundlæggende tese er, at dronekrigen implicerer en 'spaltet' såvel som 'splintret' erfaring af, hvad man traditionelt har forbundet med at føre krig: I fjernkrigens tidsalder er skærmkrigeren ikke længere konfronteret med sin fjende 'ansigt til ansigt, ${ }^{5}$ men indtager, som nævnt, i højere grad voyeurens rolle - en slags 'peeping tom' bevæbnet med missiler, hvis privilegium det er at kunne iagttage uden selv at blive iagttaget, dræbe uden selv at være i skudlinjen. Det afgørende nye ved dronen er imidlertid ikke kun selve distancen (her har eksempelvis krydsermissiler og langtrækkende, interkontinentale raketter en meget længere historie), men også kvaliteten og detaljegraden i billederne. Modsat tidligere tiders luftovervågning med for eksempel lænkeballoner, spionfly og satellitter er dronen udstyret med så avancerede og højteknologiske optiske linser, at den formår at bringe en helt ny grad af intimitet i spil i krigen mod terror; men samtidig en intimitet der, som vi skal se, er særdeles ambivalent i sin natur.

Resten af artiklen falder i tre dele: I første del vil jeg demonstrere, hvordan voyeuristisk intimitet knytter sig til dronens blik $i$ en af de nok mest udbredte populærkulturelle repræsentationer af dronekrig, ${ }^{6}$ nemlig Showtimes tv-serie Homeland (2011-). Når valget falder på lige netop denne tv-serie som kulturelt analyseobjekt, er det (udover seriens brede popularitet), fordi den i særlig høj grad tematiserer overvågningens relation til den følelsesmæssige erfaring af voyeurisme, mani, paranoia og ikke mindst intimitet. På baggrund af disse analyser vil jeg, for det andet, adressere den voyeuristiske intimitet som en spaltet erfaring, eller hvad jeg også kalder en 'bipolar konfiguration'. Og for det tredje vil jeg nuancere denne bipolaritet ved at foreslå, hvordan dronen også skaber en splintret erfaring som i sin fragmentariske og paranoide logik og struktur kan minde om mosaikkens. Artiklens overordnede argument er, at alle tre trin peger på en basal splittelse eller ligefrem opløsning af måden, vi forstår krig på; en splittelse, der i Homeland kommer til udtryk i to blikke: det voyeuristiske og det intime blik.

\footnotetext{
${ }^{4}$ Fra Sun Tzus Art of War: "If you know the enemy and know yourself, you need not fear the result of a hundred battles." Citeret fra Gregory (2008).

${ }^{5}$ Denne forestillingen om krig som en duel, hvor to ligeværdige parter mødes ansigt til ansigt, som i en duel, bygger på Carl von Clausewitzs klassiske definition fra Vom Kriege (1832), (Chamayou 2015, 33).

${ }^{6}$ Homeland har ifølge Showtime ligget og svinget mellem en til to millioner seere per sæson i gennemsnit.
} 
Krig, krop og kage

I fjerde sæson af Homeland leder vores hovedperson, den maniodepressive CIA-agent Carrie Mathison (Claire Danes) en amerikansk dronebase i Afghanistan. Sæsonens første episode, der kendetegnende bærer titlen 'The Drone Queen', åbner med Carries godkendelse af et luftangreb på en bygning, hvor en eftersøgt terrorist formodes at opholde sig. Efter at have overværet de lydløse billeder af bygningen, der går op i røg, præsenterer hendes stab hende for en fødselsdagskage med inskriptionen 'The Drone Queen'. En bizar scene, der antyder, hvor rutinepræget den hverdagslige praksis med fjernstyrede bomber er blevet. Ikke mindst da det viser sig, at den eftersøgte terrorist slet ikke var i bygningen, som til gengæld husede et afghansk bryllup. Den skarpe kontrast mellem bombningen af 40 civile bryllupsgæster og den kollegiale jovialitet i kontrolrummet bliver ikke mindre af, at personalet derpå synger 'She's a jolly good fellow', efterfulgt af Carrie, der puster lysene ud, næsten som havde vi været til børnefødselsdag. Associationerne til familiær nærhed og hverdagsliv forstærkes yderligere af krydsklipningen til næste scene, hvor Carrie fra sit hotelværelse ringer til sin etårige datter, som hun har overladt til sin søster i Amerika.

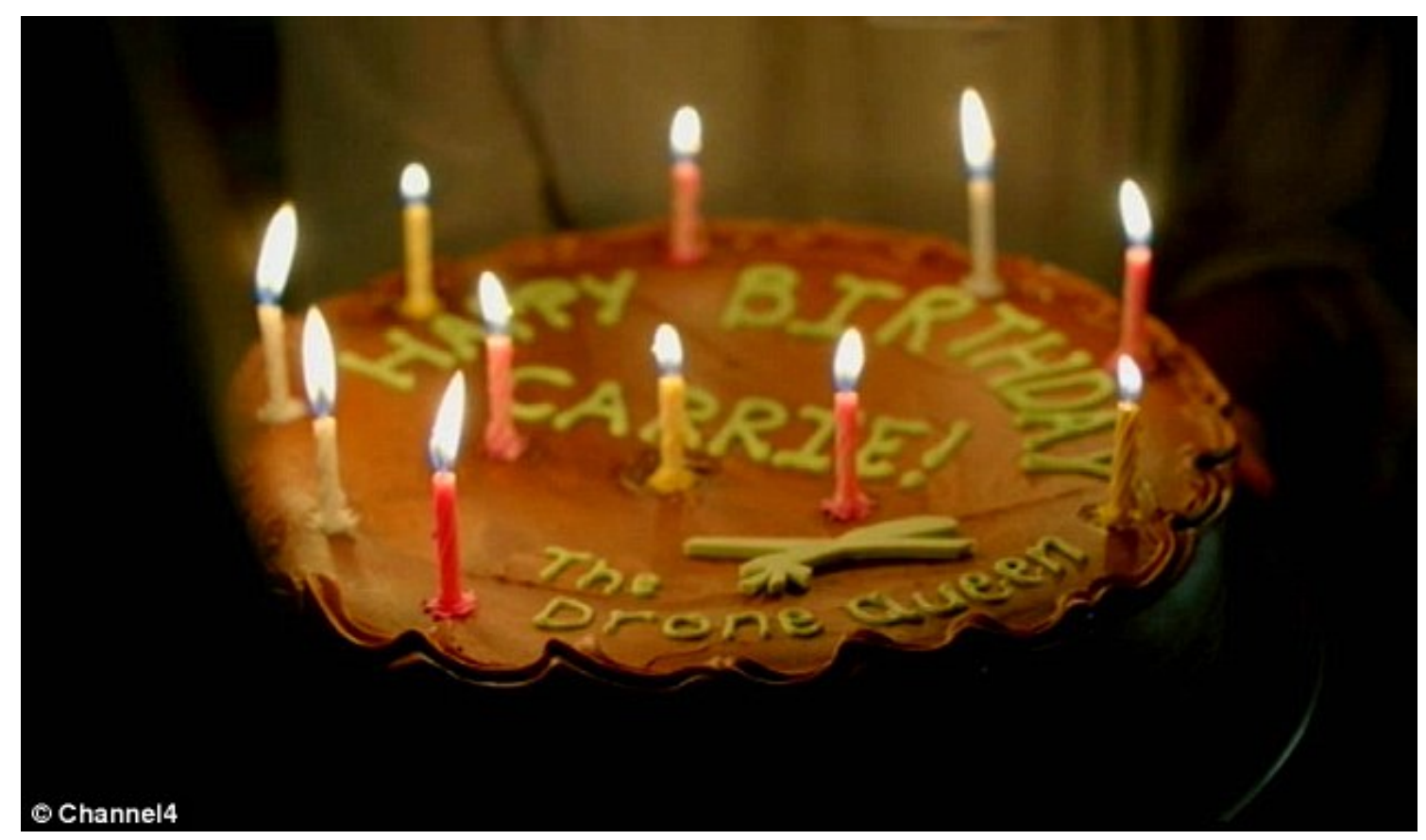

Fig. 1. Homeland, Sæson 4, Episode 1, 'The Drone Queen' (5. oktober 2014), 05:56 
I begge scener er intimiteten naturligvis langt fra den, Bryant beskriver i interviewet ovenfor som en langvarig, voyeuristisk overvågning af personers privatliv. Snarere er scenen et eksempel på den hverdagsintimitet, der opstår i mødet mellem militær og civil orden. En intimitet, som i høj grad kendetegner dronepiloternes virkelighed, da de konstant skal tilpasse sig skiftene fra 12 timers fjernkrig til de næste 12 timers familieliv. ${ }^{7}$ Ikke desto mindre antyder 'krig-og-kage'-scenen mere end blot kollegial hygge. Den indvarsler ét af de absolut vigtigste temaer i Homeland, nemlig den ambivalente intimitet, der kendetegner droneovervågning i fjernkrigens tidsalder. Dronekrigerens krop er således langt fra totalt udvisket, som Chamayou antyder i det indledende citat, men snarere geografisk forskudt og følelsesmæssigt forvrænget.

En anden vigtig scene fra samme episode er med til at illustrere denne ambivalente intimitet, der kendetegner dronevoyeurens blik: Dagen efter krig-og-kagescenen inspicerer Carrie de tragiske konsekvenser af angrebet ved hjælp af videosignalet fra en Reaper-drone. Udtrykket i Carries ansigtsudtryk viser tydeligt, at hun er følelsesmæssigt berørt over de mange civile dræbte efter hendes fejlagtige angreb. Men iblandet smerten og selvbebrejdelsen fornemmes også tydeligt en nysgerrighed rettet mod de sårede og deres pårørende, der møjsommeligt arrangerer de døde i lige rækker. Hun er i sandhed en voyeur, der lever sig fuldt og helt ind i de menneskers liv, som hun netop har forvandlet radikalt. Det er en voyeurisme, der bevæger sig på kanten af skopofili, det vil sige den 'schaulust', som Freud anså som et basalt instinkt i barndommen og forbandt med nydelsen ved at se den Anden (Jay 1993, 332) - men en nydelse, som samtidig er forbundet med vold og overmagt.

Blandt rækkerne af døde kroppe spotter hun en dreng, der knæler ved siden af sin døde søster. Og hvad mere er, drengen spotter også hende. Med blikket rettet stift opad mod dronen fanger han Carries blik i en blanding af sorg, afsky og bebrejdelse. En illusion af egentlig øjenkontakt etableres således gennem krydsklipningen fra drengens til Carries stærkt følelsesladede blik. Og selvom denne illusion selvfølgelig er langt fra en ægte, gensidig $\varnothing j$ jenkontakt, iscenesætter den et egentligt 'modblik' til dronen. En iscenesættelse, der giver drengen 'the right to look', som billedteoretikeren Nicholas Mirzoeff kalder den autonomi og gensidighed, der er helt nødvendig for at kunne anerkende og i det hele taget 'se' den Anden (Mirzoeff 2011).

\footnotetext{
${ }^{7}$ Selv for klassiske soldater er overgangen fra krig til fred en notorisk vanskelig fase, hvor omstillingen fra én moralsk verden til en anden og reintegrationen i det civile liv kræver perioder med dekompression. For dronepiloter, der 'pendler til krigszonen' er denne omstillingsfase langt mere intens, idet de to gange om dagen skal omstille sig stort set uden nogen overgang (Chamayou 2015, 119). Af samme grund er dronepiloterne, ifølge Gregory (2014), provokerende blevet kaldt 'prøverumskrigere' ('cubicle warriors').
} 


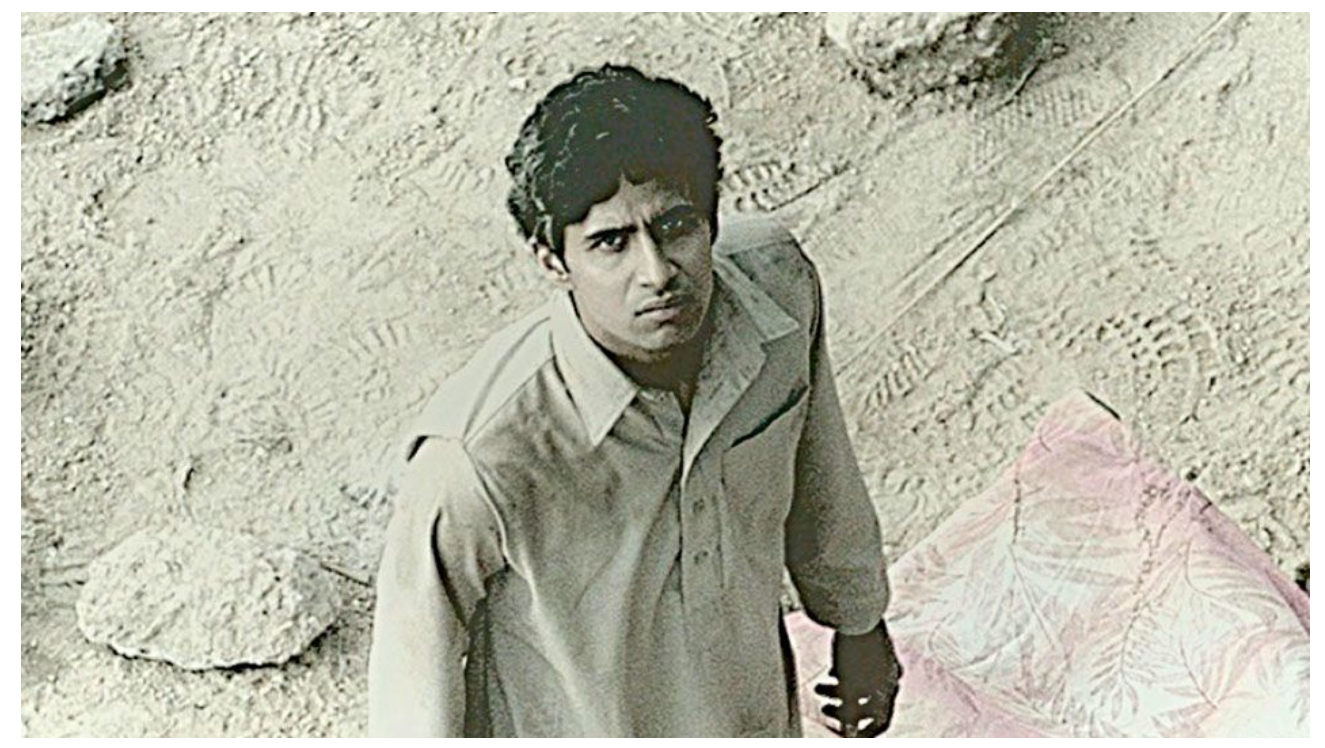

Fig. 2. Homeland, Sæson 4, Episode 1, 'The Drone Queen' (5. oktober 2014), 20:21

Denne iscenesættelse af modblikket er - udover den åbenlyse visuelle kontakt mellem de to sæt blikke - konstrueret af flere forskellige delelementer, herunder lydsporet, hvor en elegisk baggrundsmusik knytter billederne af drengen på jorden til billederne af Carrie bag skærmen. Den lydlige affinitet bliver yderligere forstærket gennem sammensmeltningen af cikadernes summen på landjorden og computerskærmenes summen i kontrolrummet. En lydlig fusion af insekt og maskine, der metonymisk peger på dronen som medium, da det engelske ord 'drone' som bekendt refererer til dels insektet bien, ${ }^{8}$ og dels en monoton, maskinel summelyd. Man kunne udlægge scenens billeder og lyd som en ildevarslende summen fra dronedronningen, Carrie, og hendes intensivering af droneovervågningen i resten af sæsonen. ${ }^{9}$

Modblikket, som scenen konstruerer, bryder altså med dronens ensidige og voyeuristiske blik og erstatter det for et øjeblik af noget andet; noget der næsten kunne minde om ægte nærvær i kraft af den intensitet, der udspiller sig mellem Carrie og drengen. Men også kun næsten. For drengen ser naturligvis intet andet en den svage silhuet af dronen som en mikroskopisk prik på himlen. Uanset hvor intenst sådanne modblik kan ramme dronevoyeuren, vil dronens omnipotente militante overvågning altid være overlegen. Intimiteten er, med andre ord, meget langt fra den intensitet, respekt og omsorg, der ifølge Mirzoeff rummes i en gensidig øjenkontakt (Mirzoeff $2011,1)$, men er snarere en 'falsk intimitet', som Gregory kalder det (Gregory 2014, 9). Ikke desto mindre er det intime en central del af Carries karakter. Netop i kraft af sin

\footnotetext{
${ }^{8}$ Dronebien er den brodløse han-bi, hvis eneste funktion er at parre sig med dronningebien for derefter at lægge sig til at dø. Den dødelige symbolik i Carries øgenavn 'The Drone Queen' bliver således endnu mere signifikant.

${ }^{9}$ Ifølge kunstneren og aktivisten Susan Schuppli er det lydlige aspekt af dronekrig en mindst lige så væsentlig faktor som det visuelle, eftersom civile, der lever under dronerne, bliver dagligt terroriseret af den konstante summende lyd fra de flyvende krigsmaskiner uden at vide, hvornår eller hvor deres missiler slår ned (Schuppli 2014).
} 
bipolare lidelse rummer hun både det kølige overblik og et brændende begær efter den intime detalje. Hendes paranoia og maniske jagt på terrorister gør hende bogstaveligt talt besat af sit job. Hun er med andre ord konstant splittet mellem to poler: På den ene side et køligt blik for de større sammenhænge og på den anden side et lidenskabeligt behov for menneskelig kontakt og nærhed. Hun er kort sagt et levende eksempel på den spaltede erfaring, Gregory taler om som 'remote split operations'; en spaltning mellem det geografisk fjerne og det følelsesmæssigt nære.

Carries trang til nærvær finder konkret udtryk i kompromisløse og ofte promiskuøse metoder til at skaffe sig informationer. Eksempelvis planlægger hun - efter at have fundet ud af, at drengen på skærmen i scenen ovenfor er nevø til den eftersøgte terrorist, hun jagter - at forføre ham og dernæst bruge den vundne tillid til at føre ham til terrorist-onklen. Nøjagtig ligesom hun i seriens første sæson bruger sig selv og sin krop til at forføre den hjemvendte krigshelt, Sergent Nick Brody, for på den måde at afsløre ham som konverteret terrorist. ${ }^{10}$ I begge tilfælde lykkes hun med sin plan, og den intime omgang med kilderne leder hende på rette spor. Igen taler vi selvfølgelig ikke om en 'ægte' intimitet, men om nøje planlagt og snedigt udført overvågningsmagt, der camouflerer sig som en art 'falsk' eller voyeuristisk intimitet. Det er da også værd at bemærke, at serien i høj grad spiller på dette ambivalente nærvær, eftersom det ofte er uklart, hvornår Carrie 'faker' sine følelser, og hvornår hun er oprigtigt følelsesmæssigt berørt. Denne ubestemmelighed driver således ikke blot Carries karakter, men er samtidig en central narrativ motor i Homeland.

\section{Bipolar konfiguration}

Ubestemmeligheden i den flimrende dialektik mellem på den ene side voyeuristisk distance og på den anden side nærvær og intimitet er afgørende for, hvad jeg vil kalde en 'bipolar konfiguration af dronens imaginære'. Denne bipolaritet kan som nævnt ses i forlængelse af Gregorys idé om dronepilotens spaltede erfaring. Men til forskel fra Gregorys 'remote split operations' er det en bipolaritet, der ikke alene dominerer den individuelle erfaring af dronekrig, men også den bredere kulturelle og politiske forestillingsevne - hvad jeg har beskrevet som 'dronens imaginære'. Den imaginære bipolare konfiguration træder særligt tydeligt frem i Homeland gennem Carries figur: Carrie er bipolar, men hendes maniske faser og hendes evne til både at se de brede linjer og opfange de væsentlige detaljer er netop, hvad der gør hende til en fremragende spion. Man kunne hævde, at Carries bipolare personlighed spejler det paranoide politiske regime, hun arbejder for: En overvågningskultur med voyeurisme og intimitet som dominerende poler i en manisk jagt på stadigt flere og mere følsomme informationer.

\footnotetext{
${ }^{10}$ For nærmere diskussion af spørgsmålet om Carries køn, krop og seksualitet i Homeland, se (Steenberg 2015; Bradshaw 2013; Negra 2015)
} 
Med denne argumentation følger jeg billedteoretikeren W. T. J. Mitchells diagnose af krigen mod terror som en "galskab, der er blevet operationaliseret" (Mitchell 2015, 178). I sin seneste bog Image Science (2015) skelner han mellem 'terror' og 'terrorisme' som en grundforskel mellem følelse og taktik. Mens den tekniske betydning af ordet 'terror' betegner en ekstrem frygt, panisk angst og paranoia, er 'terrorisme' omvendt det, der igangsætter disse følelser. Krigen mod terror er derfor, ifølge Mitchell, den rene 'galskab', netop fordi den i udgangspunktet retter sig mod følelser frem for fornuft; mod symptomer frem for årsager. Krigen mod terror, herunder droneoperationer, er kort sagt en følelsesladet krig mod følelser; en tautologi og dermed en krig som i sagens natur er umulig at vinde, da den skizofrent pendulerer mellem det rationelle og det emotionelle (Mitchell 2015, 179).

Både i Image Science og i forelæsningen 'Madness and Montage' ${ }^{11}$ adresserer Mitchell denne 'paranoide skizofreni' direkte i Homeland. Her overfører han Carries personlige sindslidelse på en mere generel og nutidig optagethed af big data eller det, han kalder 'iconomania' (Mitchell 2014): En billedmani, der finder udtryk i begæret efter den totale overvågning (tæt beslægtet med voyeurisme og skopofili), visualiseret som et gigantisk panorama med svimlende mængder visuelle informationer. Denne billedmani minder om den, der præger nutidens dronekrig og dominerer dronens på én gang panoptiske og intime blik: En overvågningsmani der er helt central i Homeland lige fra seriens første sæson, hvor Carrie $\mathrm{i}$ al hemmelighed får installeret kameraer $\mathrm{i}$ Brody-familiens hus og fra sin egen dagligstue overvåger dem døgnet rundt, og til fjerde sæson, hvor hun i sin egenskab af 'dronedronning' overvåger alt fra terrorister til uskyldige civile ved hjælp af dronernes konstante videosignaler.

Med begrebet 'ikonomani' og forestillingen om den totale overvågning i form af et panoptisk panorama ${ }^{12}$ bygger Mitchell på kunsthistorikeren Aby M. Warburgs 'Billedatlas' eller 'Mnemosyne', der direkte oversat betyder 'erindring'. Billedatlasset (1924-1929) var Warburgs utopiske forsøg på at kortlægge antikkens efterliv igennem et overvældende billedmateriale. Ved at samle billeder af særlig stor symbolsk og følelsesmæssig kraft skabte han en montage, hvor den kulturhistoriske erindring på én gang kunne overskues $\mathrm{i}$ sin helhed og samtidig fornemmes gennem de enkelte, gådefulde detaljer og 'polariteter'. For Mitchell er Warburgs billedatlas et 'vanvittigt' værk, forstået på den måde, at det udtrykker den gales evne til at se klart. Og hvad har så det at gøre med Carries overvågningspraksis i Homeland?

Ligesom Warburg ironisk nok selv led af skizofreni, indtager Carrie rollen som den gale, der kan se noget, ingen andre kan se. Hun er, ifølge Mitchell, en Cassandrafigur, ${ }^{13}$ hvis paranoia og mani tillader hende at se trusler, som er usynlige for alle andre.

\footnotetext{
${ }^{11}$ Forelæsningen "Madness and Montage": The Picture Atlas as Symptom and Therapy from Aby Warburg to A Beautiful Mind" at Image Operations, ICI Berlin, April 2014.

${ }^{12}$ Den panoptiske dimension $\mathrm{i}$ droneovervågningen (som den udfoldes af både Jeremy Bentham og Michel Foucault) er en diskussion for sig, men er af pladshensyn udeladt her.

${ }^{13}$ Ifølge græsk mytologi var Cassandra en trojansk prinsesse, hvis skønhed fik Apollon til at give hende profetens gave - men da hun afviste ham, nedkaldte han en forbandelse over hende, så ingen nogensinde
} 
Carries forbandelse er - på linje med den mytologiske Cassandra-figur - at ingen tror hende til trods for, at hun oftest viser sig at have ret $\mathrm{i}$ sine intuitive fornemmelser. Mitchell hæfter sig særligt ved en scene fra seriens første sæson, hvori Carrie, i én sine maniske faser kommer på sporet af et stort anlagt terrorkomplot udtænkt og orkestrereret af terroristen Abu Nazir. Carries rolle minder her om den klassiske detektivs, idet hun indsamler spor og informationer, som hun organiserer visuelt på sin billedvæg (den obligatoriske opslagstavle i enhver detektivhistorie) fyldt med fotografier af mistænkte, ledetråde, genstande, avisudklip, etc. Kort sagt et Billedatlas, der minder om Warburgs Mnemosyne. Men billedatlasset udtrykker samtidig en dobbelthed, påpeger Mitchell: På den ene side er det et "diagnostisk instrument [...] et atlas, som kan udstille og fortolke symptomer," mens det på den anden side bliver "et symptom i sig selv, et clou om detektivens egen patologi" (Mitchell 2014). Carries billedvæg rummer netop denne dobbelthed, idet den i løbet af serien - og i takt med hendes eskalerende mani - vokser sig gradvist større og mere kaotisk for i slutningen af sæsonen at ende i ét stort rod af udklip og løse billedfragmenter. Et rod, der afspejler hendes tiltagende psykotiske tilstand, men som hendes chef, Saul Berenson, hjælper hende med at restrukturere til en meningsfuld sammenhæng.

Det særlige ved Carries billedvæg er, at den følger et avanceret system af farvekoder, hvor hver farve symboliserer et bestemt mønster i terroristen Abu Nazirs aktiviteter. Men montagen afslører samtidig et kritisk tomrum i kronologien markeret med farven gul: 'The fallow yellow,' som Carrie forklarer Saul, inden hun indser, at fraværet af gule aktiviteter må betyde et tab eller en tragedie; at Nazir sørgede i den gule fase. Og ganske rigtigt viser det sig, at terroristen mistede sin søn i netop denne periode som følge af et amerikansk droneangreb. Allerede fra første sæson af Homeland er dronens imaginære således i spil som en bipolar konfiguration, der mudrer grænserne for, hvad der traditionelt er blevet opfattet som nært og fjernt, intimt og distanceret $\mathrm{i}$ krigszoner. Det er fortvivlelsen og hævnen over dronedrabet på sønnen, der er katalysatoren i Nazirs terror; en følelse forud for en taktik. Det er altså den intime detalje i Nazirs privatliv, der for alvor leder Carrie på rette spor, så hun i sidste ende får afværget den lurende terrortrussel.

Jeg har indtil nu argumenteret for, hvordan dronens imaginære kan betragtes som en bipolar konfiguration; som en spaltet erfaring af på én gang at være langt fra og helt tæt på. Visuelt kommer denne spaltede erfaring til udtryk som en splittelse mellem to oppositionelle optikker: På den ene side en stræben efter det totale panoptiske overblik og på den anden side et dyk ned i de enkelte dele af billedet, de intime og personlige detaljer kendetegnet ved affektive tilstande og individuelle følelser. Hvad der dog også gerne skulle være blevet klart er, at denne bipolaritet ikke skal forstås som en simpel modsætning mellem to uafhængige principper. Det nære og det fjerne, voyeurismen og intimiteten, er i den grad vævet ind i hinanden - som vi har set symboliseret i Carries

ville tro hendes altid sande forudsigelser. På samme måde lider Carrie, ifølge Mitchell, under Cassandrakomplekset (Mitchell 2014). 
bipolare karakter. Der er således snarere tale om en ustabil tilstand, end om et klart oppositionspar. "Not a 'split', but a shattered personality." som Mitchell udtrykker det om skizofrenien i den amerikansk ledede krig mod terror (Mitchell 2015, 178). Denne splintrede erfaring af dronekrig vil jeg afslutningsvis forsøge at forstå ved hjælp af mosaikken som metafor.

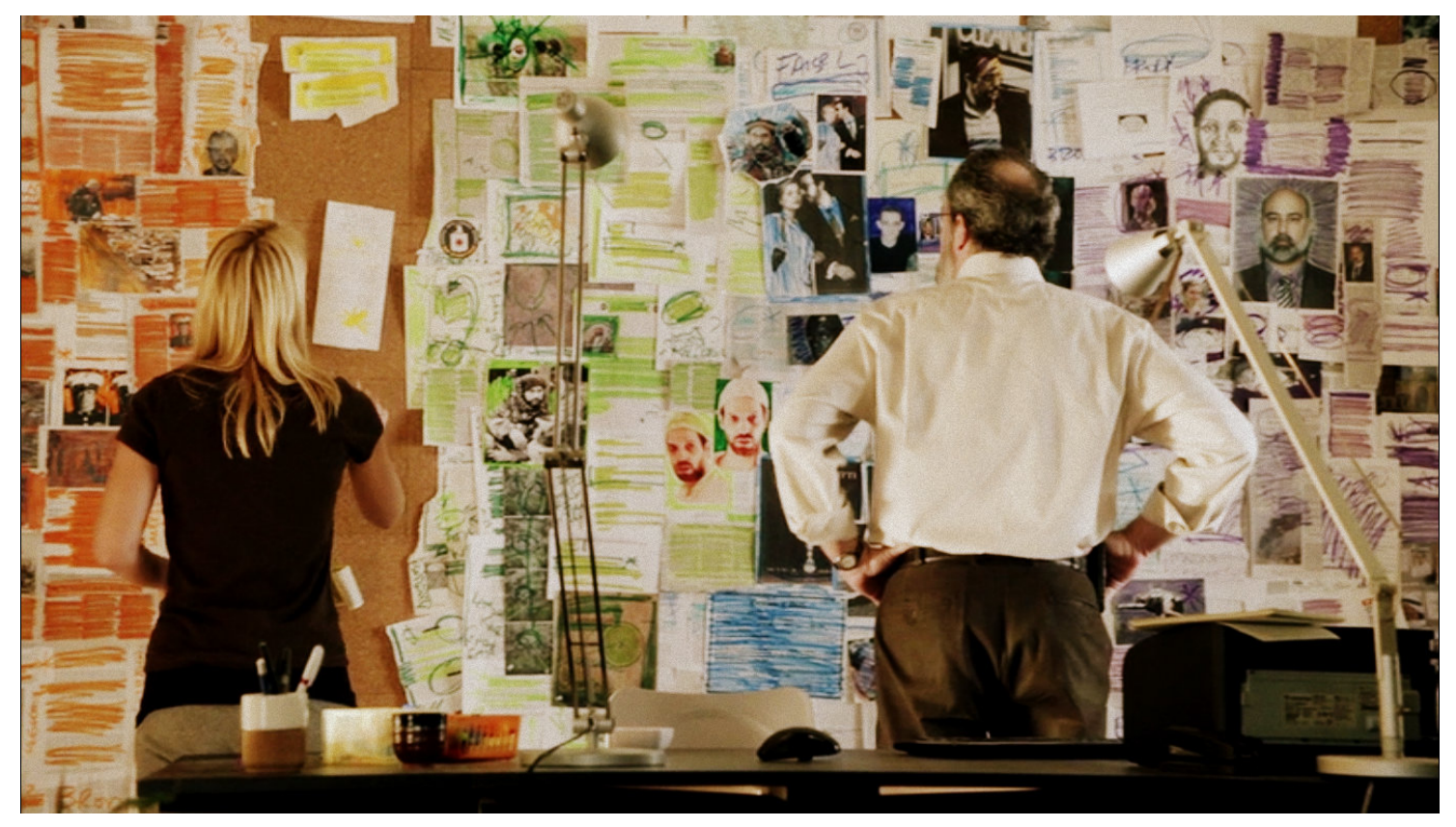

Fig. 3. Homeland Sæson 1, Episode 11 'The Vest' (11. december 2011), 41:54

\section{Mosaikmetoden: Dronedronningens paranoia}

På samme måde som mosaikken er sammensat af en assemblage af bittesmå stykker farvet glas eller sten, ligeså er dronens bipolare konfiguration sammensat af detaljerede enkeltdele, der tilsammen skaber et større billede, en mosaik, som kan overskues i sin panoramiske helhed af dronevoyeuren. Med andre ord en 'splintret' erfaring af en mængde delelementer, som må genorganiseres til et meningsfuldt hele. Men også i mere teknisk forstand virker dronen som en mosaik. Den optiske teknologi installeret i de amerikanske Predator og Reaper-droner anvender højresolutions-kameraer, der lige præcis opererer efter mosaikkens logik. Navnene på disse kamerateknologier, 'The Gorgon Stare' og 'Argus-IS'-systemet, afslører inspirationen fra den græske mytologi: Mens gorgonernes blik kunne forvandle folk til sten (med Medusa som det mest berømte eksempel), var Argus til gengæld det 'altseende' monster med hundredvis af øjne, også kaldet Pantopes. ${ }^{14}$ På samme måde benytter Argus-systemet hundredvis af små digitale kameraer, der tilsammen danner en mosaik af højtopløselige billeder og

\footnotetext{
${ }^{14}$ Heraf navnet for Benthams berømte Panoptikon.
} 
dækker et område på op til 90 kvadratkilometer ned til mindste detalje (Gayle 2013). Dronens blik er således en mosaik i sin mest bogstavelige tekniske betydning.

Men også andre aspekter af dronekrig følger mosaikkens struktur. En væsentlig del af dronernes opgaver går som bekendt ud på at indhente informationer og efterretninger ved hjælp af luftovervågning, såkaldt 'Imagery Intelligence' (IMINT), ${ }^{15}$ som siden bliver brugt til at udvælge militære mål. For amerikanske efterretningsanalytikere er en udbredt metode i denne overvågningspraksis blevet kaldt 'the Mosaic Method', hvor hovedprincippet er, at helheden er mere end summen af delene. Mosaikteorien sammenlignes derfor ofte med et puslespil, hvor de enkelte brikker ikke i sig selv udgør en definerbar trussel, men kan afsløre større trusselsscenarier, når de kombineres med andre brikker og informationsstumper (Rolington 2013; Goodwin 2010; Pozen 2005).

I Homeland bruger Carrie samme strategi i jagten på terroristen Abu Nazir. Som det er tilfældet med hendes farvekodede billedvæg, minder hendes arbejdsmåde særligt hendes dobbeltblik for både helheden og detaljen - påfaldende om mosaikmetoden. Det er specielt tydeligt i en scene fra samme episode som billedvæggen ovenfor, hvor hun i en af sine karakteristiske maniske talestrømme argumenterer mod sin chef, Sauls, mere simple teori:

"Well, its wrong! Or... it's incomplete. [...] Walker is not even critical. He's just a part, a piece, a pixel, a pawn. He has no importance. There is a bigger pernicious plot. [...] We have to code it, collide it, collapse it, contain it." (Showtime, Homeland, 2011, Sæson 1, episode 11)

Her adresserer Carrie i en serie af p-ord selve essensen af mosaikteorien: Ved at omtalte den hovedmistænkte i Sauls teori, Walker, som en biperson - en uvæsentlig brik, "a part, a piece, a pixel, a pawn" - er hendes budskab, at han kun er den lille del af et større 'pernicious plot'. Selv på det sproglige plan former bogstavrimet mellem de mange pord et større hele, en mosaik af p-lyde. På samme måde som hendes farvede billedmontage - hvor hver farve ligesom mosaikkens farvede glas udgør en del af mosaikken - samler hun i denne matrix de enkelte dele sammen til et større billede. Et billede der kun giver mening ved at kode, fortolke og sammenholde delene; eller, som hun formulerer det, må man først 'code' og 'collide it' for dernæst at 'collapse' og 'contain it', hvis man vil forhindre et nyt storstilet terrorangreb.

I citatet er det desuden værd at bemærke valget af ordet 'pixel', som åbenlyst refererer til digital billedteori. Digitale billeder er jo sammensat af millioner af pixels, der, igen ligesom mosaikken, ikke har afgørende betydning i sig selv, men som i kraft af hinanden danner et genkendeligt billede på skærmen. Ordet pixel er i virkeligheden en

\footnotetext{
${ }^{15}$ Ligesom 'Signals Intelligence' (SIGNINT) står denne form for teknisk dataindsamling i modsætning til såkaldt 'Human Intelligence' (HUMINT), der henter sine informationer fra menneskelige kilder såsom spioner, indhentere, diplomater, politikere, embedsmænd, forskere og specialister, lokale og journalister (Rolington 2013, 119).
} 
sammenføjning af ordene 'picture' og 'element' og indikerer således sammensmeltningen af det visuelle og materielle i den mindste enhed på skærmen. Med citatet sætter Carrie kort sagt fingeren på, hvordan dronen både i metaforisk og teknisk forstand samler (i sig selv ubetydelige) fragmenter og brudstykker til en mosaik, der i sidste ende kan åbenbare det helt store masterplot.

Denne strategi kan, ligesom mosaikteorien i $\emptyset$ vrigt, kritiseres for at være manisk og paranoid grænsende til det hysteriske i sin bestandige bestræbelse på at finde nye mønstre, nye motiver og nye konspirationer at afsløre (Goodwin 2010; Pozen 2005). Som juristen Joseph Margulies skriver, er mosaikteorien et system, der konstant udvider sig selv ved at generere stadig nye interessepunkter, der åbner for stadig flere forbindelseslinjer og konspiratoriske sammenhænge. Som han skriver, "Only through this painstaking process will a mosaic finally emerge that captures the complete picture of the enemy and its plans, or so the Administration maintains" (Margulies 2006, 21). Mosaikteorien fungerer således mere eller mindre ud fra ikonomaniens præmis ved til stadighed at føje nye billeder, nye trusler og nye navne til den amerikanske regerings berygtede 'kill list' - droneæraens svar på westernfilmens 'Wanted'-plakat. ${ }^{16}$ Alt sammen i bestræbelsen på at skabe et stadig mere komplet og på samme tid detaljeret trusselsbillede. Ironisk nok indeholder denne bestræbelse et indbygget paradoks, eftersom den konstante udvidelse af mosaikken uundgåeligt fører til stadig flere potentielle trusler at forholde sig til. Mosaikteorien lider således af, hvad Jacques Derrida beskrev som 'archive fever', det vil sige en endeløs akkumulation af tilføjelser, udvidelser, appendikser, tillæg og noter til, hvad han kaldte for 'anarkivet. ${ }^{17}$ Problemet med anarkivet er, at ophobningen af data i princippet aldrig stopper, og bestræbelsen på at skabe det definitive overblik derfor reelt er håbløs. Tilsvarende er den repetitive føjning af navne til Washingtons 'kill list' og strømmen af droneangreb polemisk beskrevet af Chamayou som en endeløs voldsspiral, hvis eneste mål er at eliminere fremspirende trusler i samme høje tempo, som nye rekrutteres (Chamayou 2015, 71). Denne praksis spejler således også Carries febrilske terroristjagt i Homeland, der om noget er drevet af 'arkivfeber'. Derrida beskriver denne febrilske søgen som en 'mal d'archive,' der både dækker over en galskab, men også en passion (Derrida, 91). En passion som driver ikke blot Carrie, men også selve serien, eftersom hun, for at holde serien kørende og producere mere spænding og nye sæsoner, er tvunget af en narrativ nødvendighed til konstant at finde nye brikker, der kan føjes til den paranoide mosaikstruktur.

At mosaikteorien er drevet af en paranoid logik, har også flere jurister påpeget i forbindelse med $\emptyset$ get censur af ellers offentligt tilgængelige informationer fra den amerikanske regering (Goodwin 2010; Pozen 2005). Denne kritik går altså på en

\footnotetext{
${ }^{16}$ I Washington var der under Obama-administrationen en tradition for hver tirsdag (de såkaldte 'Terror Tuesdays') at gennemgå den berygtede 'kill list,' en prioriteret dødsliste med navne på terrorister, før den blev sendt til præsidentens godkendelse (Chamayou 2015, 46).

${ }^{17}$ Derrida formulerer 'anarkivet' som en åbenhed, der 'produces more archive, and that is why the archive is never closed. It opens out of the future" (Derrida 1995, 68).
} 
'omvendt' mosaikmetode, det vil sige en paranoid idé om at selv tilsyneladende uskadelig information fra myndighederne kan blive misbrugt af terrorister, hvis det stykkes sammen af en velinformeret observator. Paranoiaen, over for de ydre såvel som de indre linjer, er, som det efterhånden gerne skulle stå klart, en helt central følelse i Homeland. Det afsløres allerede i titelsekvensen, som vises i starten af hver episode, ${ }^{18}$ hvor vi i en surrealistisk, mareridtsagtig klipning ser en desperat Carrie fare vild i en hæklabyrint (i korte glimt endda med en løvemaske på), mens en voice-over med hendes stemme siger: "Fuck! I missed something once before. I won't... I can't let that happen again." Som karakter er Carrie altså drevet af en besættelse af ikke at overse noget; hun er styret af en slags 'mistankens hermeneutik,' altså idéen om, at der altid gemmer sig en skjult sammenhæng, hemmelig dagsorden eller latent magtstruktur bag ethvert udsagn. ${ }^{19}$ I essayet 'Paranoid Reading and Reparative Reading, or, You're so Paranoid, You Probably Think this Essay is about You' problematiserer affektteoretikeren Eve K. Sedgwick denne tradition for at være blevet en automatreaktion i den vestlige, kritiske tradition (Sedgwick 2003). En tradition der ifølge Sedgwick har lagt grundstenen til den paranoide jagt på skjulte betydninger, som dominerer vestlig tankegang - og som altså også finder udtryk i dronekrigens paranoide overvågning repræsenteret i en populær tv-serie som Homeland.

Reparation af en splintret erfaring

Modsvaret til den 'paranoide læsning,' Carrie laver af alle de små brudstykker og fragmenter i sin mosaiske billedvæg, er, hvad Sedgwick kalder en 'reparativ læsning'. Det vil sige en læsning, der, frem for at være drevet frem af negative og aggressive følelser såsom frygt og paranoia, fokuserer på positive følelser - som håb, kærlighed og intimitet - og på at genopbygge det ødelagte eller sårede. Måske kan vi ved hjælp af en sådan reparativ læsning af Homeland ikke bare forsøge at forstå den paranoia, der driver vestlige regeringer i kampen mod terror, men måske også ligefrem søge efter måder at 'reparere' den splintrede erfaring af dronekrig eller forene de splittede følelser, der knytter sig til dronens bipolare 'remote split operations' og dermed også komme et skridt nærmere en erkendelse af de menneskelige konsekvenser ved dronekrigens tidsalder.

Jeg indledte denne artikel med en polemisk modstilling af kamikazepiloten og dronepiloten som en forceret opfattelse af, hvad senmoderne fjernkrig er, og hvordan den kan, eller ikke kan, erfares kropsligt i dag. Måske denne forestilling i sig selv er en paranoid læsning af dronekrig som en følelseskold, maskinel operation frem for en genuin interesse $\mathrm{i}$ forandringen af den affektive tilstand, som erfaringen af dronekrig

\footnotetext{
${ }^{18}$ Titelsekvensen er et fast tilbagevendende element $\mathrm{i}$ hver episode, dog med variationer $\mathrm{i}$ de senere sæsoner, hvor eksempelvis en Reaper-drone tilføjes.

${ }^{19}$ Litteraturteoretikeren Paul Ricoeur tilskrev 'Mistankens Hermeneutik' den kritiske tradition fra Marx, Nietzsche, Freud og frem (Ricoeur 1970).
} 
(også) er? For en paranoid læser følger dronekrigen forventelighedens logik. Den intense overvågning, der går forud for dronens angrebsoperationer, har som sit primære formål at samle brikkerne i puslespillet, de splintrede fragmenter i mosaikken. Men denne idé bygger på en forventning om, at mosaikken eller puslespillet rent faktisk eksisterer - eller kan rekonstrueres - i sin helhed. I bestræbelserne på at genopbygge dette 'master-billede,' hvad jeg i artiklen har beskrevet som 'ikonomani,' ligger der altså en forventning om at kunne forudsige det uforudsigelige - hvilket ifølge Sedgwick er paranoiaens logik per se. Men hvor den paranoide læsning har som mål at finde en på forhånd givet mening, er Sedgwicks pointe, at den reparative læser leder efter det uforudsigelige og overraskende (Sedgwick 2003, 146). For en reparativ læser kan det med andre ord være både nødvendigt og befriende at lade sig overraske, også selvom disse overraskelser ikke altid er lige behagelige. Men de kan også være opløftende, som de pludselige øjeblikke af nærvær og intimitet, jeg har påpeget i Homeland, der bryder med seriens ellers så dominerende voyeuristiske og paranoide positioner. Sådanne øjeblikke af pludseligt og overraskende nærvær er med til at forme den 'splittede' eller 'bipolare' erfaring, som er grundstenen i artiklens analyse af dronens imaginære. En erfaring, der dog er ustabil af natur, og derfor nemt udvikler sig til en 'splintret' erfaring, en opløsning af fragmenterne i kaos og depression. Selv for den paranoide og maniske Carrie, seriens 'drone-dronning', kræver det altså en reparativ læsning - et intimt blik for det overraskende i detaljen og hjælp fra en nær ven - at reetablere den splintrede mosaik og dermed erfare og erkende dronekrigen som den affektive tilstand, der (lidt endnu) er en væsentlig del af droneoperationer.

Figurer

Fig. 1 Still, Homeland, sæson 4, episode 1, 'The Drone Queen' (vist første gang på Showtime, 5. oktober 2014), 05:56.

Fig. 2 Still, Homeland, sæson 4, episode 1, 'The Drone Queen' (vist første gang på Showtime, 5. oktober 2014), 20:21.

Fig. 3 Still, Homeland, sæson 1, episode 11, 'The Vest' (vist første gang på Showtime, 11. december 2011), 41:54. 
Litteratur

Bradshaw, L 2013, 'Showtime's 'female problem': Cancer, quality and motherhood', Journal of Consumer Culture, vol. 13, no. 2, pp. 160-177.

Castonguay, J 2015, 'Fictions of Terror: Complexity, Complicity and Insecurity in Homeland', Cinema Journal, vol. 54, no. 4, pp. 139-145.

Chamayou, G 2015, A Theory of the Drone, The New Press, New York.

Der Derian, J 2009, Virtuous War: Mapping the Military-industrial-mediaentertainment-network, (2nd ed.), Routledge, London.

Derrida, J 1995, Archive Fever. A Freudian Impression, The University of Chicago Press, Chicago.

Jay, M 1993, Downcast Eyes. The Denigration of Vision in Twentieth-Century French Thought, University of California Press, Berkeley.

Gayle, D 2013, 'The Military Spy Drone so Powerful it can see your iPhone from 17,500 feet', Occupy.com, 29. januar 2013.

Goodwin, M P 2010, 'A national Security Puzzle: Mosaic Theory and the First Amendment Right of Access in the Federal Courts', Hastings Communications and Entertainment Law Journal, vol. 32, no. 2, 179-207.

Gregory, D 2008, 'The Rush to the Intimate. Counterinsurgency and the Cultural Turn', Radical Philosophy, no. 150.

Gregory, D 2011, 'From a View to a Kill: Drones and Late Modern War', Theory, Culture \& Society, vol. 28, no. 7-8, pp.188-215.

Gregory, D 2014, 'Drone Geographies', Radical Philosophy, no. 183, pp.7-19.

Margulies, J 2006, Guantánamo and the Abuse of Presidential Power, Simon \& Schuster (red.), New York.

Mitchell, W J T 2015, Image Science: Iconology, Visual Culture, and Media Aesthetics, University of Chicago Press, Chicago.

Mitchell, W J T 2014, 'Madness and Montage: The Picture Atlas as Symptom and Therapy from Aby Warburg to A Beautiful Mind', forelæsning holdt ved konferencen Image Operations, ICI Berlin, April 2014. Tilgængelig på: https://www.ici-berlin.org/events/image-operations/. [Tilgået 2. januar 2017].

Negra, D \& J Lagerwey 2015, 'Analyzing Homeland: Introduction', Cinema Journal, vol. 54 , no. 4 , pp. 126-131.

Power, M 2013, 'Confession of a Drone Warrior', GQ 23, oktober 2013.

Pozen, D E 2005, 'The mosaic theory, national security, and the freedom of information act', Yale Law Journal, vol. 115, no. 3, pp. 630-681.

Rolington, A 2013, Strategic Intelligence for the 21st Century: The Mosaic Method, Oxford University Press, Oxford.

Ricoeur, P 1970, Freud and Philosophy: An Essay on Interpretation, overs. D Savage, Yale University Press, New Haven.

Schuppli, S 2014, 'Uneasy Listening' in Forensis: The Architecture of Public Truth, A Franke \& E Weizman (red.), Forensic Architecture, Sternberg Press, Berlin. 
Sedgwick, E K 2003, 'Paranoid and Reparative Reading, Or, You're So Paranoid, You Probably Think This Essay is About You', in Touching feeling: Affect, Pedagogy, Performativity, Duke University Press, Durham.

Steenberg, L \& Y Tasker 2015, 'Pledge Allegiance': Gendered Surveillance, Crime Television, and Homeland', Cinema Journal, vol. 54, no.4, pp. 132-138. 